\title{
PERHITUNGAN INDEKS KEPEMILIKAN SEPEDA MOTOR BERBASIS STRUCTURAL EQUATION MODELING
}

\author{
Asma Massara $^{1^{*}}$, Andi Hildayanti ${ }^{2}$ \\ ${ }^{1}$ Jurusan Teknik Sipil Universitas Muslim Indonesia \\ Fakultas Teknik Universitas Muslim Indonesia \\ Jl. Urip Sumoharjo KM. 5, Kota Makassar, Sulawesi Selatan. 90231 \\ *E-mail: asmamassara02@gmail.com \\ 2 Jurusan Teknik Arsitektur \\ Fakultas Sains dan Teknologi UIN Alauddin Makassar \\ Jl. Sultan Alauddin No. 63, Kabupaten Gowa, Sulawesi Selatan. 92113
}

\begin{abstract}
Abstrak: Penelitian ini bertujuan untuk menunjukkan indeks kepemilikan sepeda motor di Kota Makassar dengan menggunakan metode structural equation modeling (SEM). Metode ini digunakan untuk menentukan model terbaik dalam perhitungan indeks kepemilikan sepeda motor pada masyarakat berpenghasilan rendah pada karakteristik bepergian. Analisis SEM memiliki tujuh tahapan, yaitu: (1) Mengembangkan model teoritis; (2) Mengembangkan diagram jalur; (3) Mengubah diagram jalur menjadi persamaan struktural; (4) Memilih matriks input dan jenis estimasi; (5) Mengidentifikasi model; (6) Menilai kriteria goodness of fit; dan (7) Menginterpretasikan hasil. Untuk mengukur indeks kepemilikan sepeda motor pada masyarakat berpenghasilan rendah terhadap karakteristik bepergian. Berdasarkan hasil penelitian, kepemilikan sepeda motor pada masyarakat berpenghasilan rendah pada karakteristik bepergian memiliki nilai indeks tinggi sebesar 99,3\%. Angka tersebut menunjukkan nilai yang tinggi, artinya kepemilikan sepeda motor masyarakat berpenghasilan rendah di Kota Makassar cukup tinggi.
\end{abstract}

Kata Kunci: kepemilikan sepeda motor, masyarakat berpenghasilan rendah, pemodelan persamaan struktural, software AMOS, transportasi

\section{PENDAHULUAN}

$O$ istem transportasi adalah untuk mencapai proses transportasi penumpang dan barang secara optimum dalam ruang dan waktu tertentu, dengan mempertimbangkan faktor keamanan, kenyamanan dan kelancaran, serta efisiensi waktu dan biaya. Orang perlu bergerak karena kebutuhannya tidak dapat dipenuhi di tempat ia berada. Sistem kegiatan sebagai sistem mikro yang pertama, mempunyai jenis kegiatan tertentu yang akan membangkitkan pergerakan dan menarik pergerakan dalam proses pemenuhan kebutuhan. Pergerakan yang berupa pergerakan manusia (penduduk) dan/atau barang, jelas membutuhkan moda transportasi (sarana) dan media (prasarana) tempat moda transportasi tersebut bergerak. Prasarana transportasi yang diperlukan, merupakan sistem mikro yang kedua, yang biasa dikenal dengan sistem jaringan yang meliputi sistem jaringan jalan raya, kereta api, terminal bus dan stasiun kereta api, bandar udara dan pelabuhan laut. Interaksi antara sistem kegiatan dan sistem jaringan (prasarana) 
ini menghasilkan pergerakan manusia dan/atau barang dalam bentuk kendaraan (sarana) dan/atau orang (pejalan kaki).

Kepemilikan sepeda motor dalam penelitian ini merupakan suatu daya dorong atau kekuatan yang timbul dari dalam diri masyarakat untuk memberikan kemudahan mobilitas untuk mencapai tujuan yang di inginkan. Dalam upaya kepemilikan ini terdapat suatu proses yang dilakukan masyarakat untuk memperoleh sepeda motor tersebut sesuai dengan kemampuan atau daya dukung perekonomian mereka. Secara operasional kepemilikan sepeda motor dalam penelitian ini adalah respon masyarakat berpendapatan rendah terhadap sejumlah pernyataan mengenai keseluruhan usaha yang timbul dari dalam diri masyarakat agar tumbuh dorongan untuk memiliki sepeda motor karena peran sepeda motor yang begitu penting bagi kelangsungan perekonomian keluarga sehingga dikehendaki oleh masyarakat untuk tercapai.

Studi mengenai kepemilikan kendaraan sepeda motor, terutama di kota-kota di Indonesia, masih sulit ditemui. Dalam studi ini, penulis mengutip beberapa studi mengenai kepemilikan kendaraan sepeda motor yang dilakukan di beberapa kota di Asia dan di Indonesia (Wedagama, 2009) Kepemilikan kendaraan dapat dipengaruhi oleh beberapa faktor, salah satunya adalah faktor sosio ekonomi, yaitu yang berhubungan dengan perilaku masyarakat baik selaku pengguna jalan maupun bukan pengguna jalan. Faktor sosio ekonomi yang dapat mempengaruhi kepemilikan mobil adalah jumlah anggota keluarga dan total jarak tempuh perjalanan oleh semua anggota keluarga (Wedagama, 2009).

Sepeda motor merupakan sarana utama transportasi di banyak negara yang ekonominya kurang. Hal ini terutama karena keterjangkauan sepeda motor, lebih banyak orang mampu membelinya. Hal ini juga karena kemampuan manuver yang tinggi di jalanjalan padat. Statistik lintas negara telah mengungkapkan pertumbuhan sepeda motor di negara maju dengan negara berkembang karena meningkatnya urbanisasi dan kekayaan pribadi. Sebaliknya, dinegara yang sedang maju pertumbuhan mobil dengan bertambahnya pendapatan (Pongthanaisawan \& Sorapipatana, 2010). Kendaraan bermotor merupakan konsekuensi yang tinggi dari populasi sepeda motor.

Kepemilikan kendaraan biasanya dipengaruhi oleh faktor sosial ekonomi (De Jong et al., 2004) dan dapat dimodelkan dengan model agregat atau terpilah. Model agregat memprediksi perubahan kepemilikan kendaraan, terutama untuk wilayah geografis selama periode tertentu. Meskipun studi empiris sebelumnya telah membahas hubungan antara kepemilikan sepeda motor dan berpendapatan. Penelitian ini difokuskan pada pemahaman bagaimana pertumbuhan ekonomi mempengaruhi sepeda motor untuk kepemilikan dan faktor-faktor apa yang mendasari hubungan ini. Secara khusus, beberapa variabel yang berkorelasi dengan pertumbuhan ekonomi suatu negara, seperti urbanisasi, kepadatan daya beli masyarakat mendorong utama untuk memiliki kendaraan pribadi khususnya sepeda motor adalah kemudahan aksesibilitas. Berkaitan dengan pembelian kendaraan yang digunakan untuk menjelaskan hubungan ini. Temuan-temuan dari studi ini bertujuan untuk meningkatkan pemahaman tentang faktor-faktor penentu mobil penumpang dan kepemilikan sepeda motor dan mekanisme yang memengaruhi pertumbuhan mobil penumpang dan kepemilikan sepeda motor.

Dari penjabaran tersebut maka penelitian ini bertujuan untuk untuk melakukan perhitungan indeks kepemilikan sepeda motor yang berfungsi untuk mengukur sampai sejauh mana kepemilikan sepeda motor pada kalangan masyarakat berpendapatan rendah di Kota Makassar terhadap karakteristik bepergian. 


\section{METODE PENELITIAN}

Penelitian ini menggunakan metode Structural Equation Modeling (SEM). Metode ini digunakan untuk menentukan model terbaik pada perhitungan indeks kepemilikan sepeda motor pada masyarakat berpendapatan rendah terhadap karakteristik bepergian. Analisis SEM akan digunakan untuk menentukan model terbaik pada perhitungan indeks kepemilikan sepeda motor pada masyarakat berpendapatan rendah terhadap karakteristik bepergian. Metode yang digunakan dalam mengumpulkan data adalah metode judgement sampling. Data dikumpulkan dengan membagikan kuesioner kepada masyarakat berpendapatan rendah di Kota Makassar. Untuk menganalisis data tersebut digunakan metode SEM dengan bantuan software AMOS.

Terdapat 7 (tujuh) tahapan dalam pemodelan dan analisis struktural yaitu:

1. Pengembangan model teoritis;

2. Pengembangan diagram alur;

3. Konversi diagram alur ke dalam persamaan struktural dan model pengukuran;

4. Memilih jenis matrik input dan estimasi model yang diusulkan;

5. Menilai identifikasi model struktural;

6. Menilai kriteria Goodness-of-Fit;

7. Intepretasi dan modifiikasi model.

Langkah-langkah tersebut memiliki syarat-syarat yang harus terpenuhi. Semua syarat tersebut harus terpenuhi agar model yang diujikan benar-benar dapat dikatakan sebagai model yang baik.

\section{Pengembangan Model Teoretis}

Langkah pertama dalam SEM adalah melalukan identifikasi secara teoretis terhadap permasalahan penelitian. Topik penelitian ditelaah secara mendalam dan hubungan antara variabel-variabel yang akan dihipotesiskan harus didukung oleh justifikasi teori yang kuat.

Misalnya saat akan melakukan penelitian terhadap kepemilikan sepeda motor, peneliti harus memahami teori transportasi mengenai hal-hal apa saja yang akan mempengaruhi kepemilikan sepeda motor. Hal ini dikarenakan SEM adalah untuk mengkonfirmasikan apakah data observasi sesuai dengan teori atau tidak. Langkah ini mutlak harus dilakukan dan setiap hubungan yang akan digambarkan dalam langkah lebih lanjut harus mempunyai dukungan teori yang kuat. Pernyataan dalam hubungan antar variabel dalam model harus memenuhi syarat kausalitas (Gudono, 2006). Tiga syarat kausalitas tersebut adalah:

a. Antara dua variabel (misalnya $X$ dan $Y$ ) sama-sama berubah nilainya. Dengan kata lain, ada kovarian ataupun korelasi antara $\mathrm{X}$ dan Y. Namun demikian syarat ini saja tidak cukup bilamana ternyata ada variabel ketiga yang menjadi penyebab keduanya.

b. Penyebab (misalnya X) terjadi lebih dahulu (dari aspek waktu) dibandingkan dengan yang disebabkan (misalnya Y). Syarat ini tampak jelas dipengaruhi oleh pandanganpandangan yang bersifat positivis.

c. Peneliti telah menghilangkan kemungkinan faktor-faktor lain sebagai penyebab perubahan variabel dependen (Misalnya Y). syarat ini cukup sulit untuk dipenuhi, karena kenyataanya di dunia ini ada banyak sekali variabel yang saling mempengaruhi. 


\section{Pengembangan Diagram Alur}

Setelah memastikan adanya hubungan sebab akibat pada tahap pertama, langkah selanjutnya yang dilakukan adalah menyusun diagram jalur untuk hubungan-hubungan tersebut. Ada dua hal yang perlu dilakukan yaitu menyusun model struktural yaitu menghubungkan antar variabel laten baik endogen maupun eksogen dan menyusun measurement model yaitu menghubungkan variabel laten endogen atau eksogen dengan variabel manifes.

Kesepakatan yang ada dalam penggambaran diagram jalur telah dikembangkan oleh LISREL, sehingga tinggal menggunakannya saja (Timm, 2002). Cara menyusun diagram jalur tersebut telah dijelaskan pada subbab penulisan dan penggambaran variabel.

3. Konversi Diagram Jalur ke Dalam Persamaan Struktural dan Model Pengukuran

Langkah ketiga adalah mengkonversikan diagram jalur ke dalam persamaan, baik persamaan struktural maupun persamaan model pengukuran. Sebenarnya langkah ini telah dilakukan secara otomatis oleh program SEM yang tersedia (AMOS). Berikut adalah contoh persamaan umum struktural:

Variabel Endogen $=$ Variabel Eksogen + Kesalahan estimasi

Sebagai ilustrasi, model persamaan adalah pengaruh antara kepemilikan sepeda motor (KSP) terhadap karakteristik bepergian (KB). Jadi persamaan strukturalnya adalah:

$$
\mathrm{KB}=\gamma 1 \mathrm{KSP}+\mathrm{z} 1
$$

Dengan z1 adalah kesalahan estimasi antara kepemilikan sepeda motor terhadap karakteristik bepergian; dan $\gamma 1$ adalah koefisien regresi kepemilikan sepeda motor.

Sebagai ilustrasi, kepemilikan sepeda motor diukur dengan tujuh indikator KSP1, KSP2, KSP3, KSP4, KSP5, KSP6 dan KSP7, maka persamaan model pengukurannya adalah:

$$
\begin{aligned}
& \mathrm{KSP} 1=\beta 1 \mathrm{KSP}+\mathrm{e} 1 \\
& \mathrm{KSP} 2=\beta 2 \mathrm{KSP}+\mathrm{e} 2 \\
& \mathrm{KSP} 3=\beta 3 \mathrm{KSP}+\mathrm{e} 3 \\
& \mathrm{KSP} 4=\beta 4 \mathrm{KSP}+\mathrm{e} 4 \\
& \mathrm{KSP} 5=\beta 5 \mathrm{KSP}+\mathrm{e} 5 \\
& \mathrm{KSP} 6=\beta 6 \mathrm{KSP}+\mathrm{e} 6 \\
& \mathrm{KSP} 7=\beta 7 \mathrm{KSP}+\mathrm{e} 7
\end{aligned}
$$

Dengan $\beta 1$ adalah loading faktor indikator KSP1 ke konstruk kepemilikan sepeda motor, $\beta 2$ adalah loading faktor KSP2 ke konstruk kepemilikan sepeda motor, $\beta 3$ adalah loading faktor KSP3 ke konstruk kepemilikan sepeda motor, $\beta 4$ adalah loading faktor KSP4 ke konstruk kepemilikan sepeda motor, $\beta 5$ adalah loading faktor KSP5 ke konstruk kepemilikan sepeda motor, $\beta 6$ adalah loading faktor KSP6 ke konstruk kepemilikan sepeda motor, dan $\beta 7$ adalah loading faktor indikator KSP7 ke konstruk kepemilikan sepeda motor; e1 adalah kesalahan pengukuran indikator KSP1, e2 adalah kesalahan pengukuran indikator KSP2, e3 adalah kesalahan pengukuran indikator KSP3, e4 adalah kesalahan pengukuran indikator KSP4, e5 adalah kesalahan pengukuran indikator KSP5, e6 adalah kesalahan pengukuran indikator KSP6, dan e7 adalah kesalahan pengukuran indikator KSP7. 


\section{Memilih Jenis Matriks Input dan Estimasi Model yang Diusulkan}

Pada awalnya model persamaan struktural diformulasikan dengan menggunakan input matriks varian/kovarian. Matriks kovarian memiliki kelebihan daripada matriks korelasi dalam memberikan validitas perbandingan antara populasi yang berbeda atau sampel yang berbeda (Ghozali, 2007). namun demikian interpretasi atas dasar unit pengukuran variabel.

Matriks korelasi dalam model persamaan struktural tidak lain adalah standardize varian dan kovarian. Penggunaan korelasi cocok jika tujuan penelitiannya hanya untuk memahami pola hubungan antar variabel. Penggunaan lain adalah untuk membandingkan beberapa variabel yang berbeda.

\section{Menilai Identifikasi Model Struktural}

Model struktural dikatakan baik apabila memiliki satu solusi untuk satu estimasi parameter. Dalam satu model sangat mungkin memiliki banyak solusi, sehingga dipilih solusi yang sesuai. Pemilihan solusi yang sesuai itu yang sering disebut dengan masalah identifikasi.

Hal yang berkaitan dengan masalah identifikasi model struktural adalah ketika proses estimasi berlangsung, sering diperoleh hasil estimasi yang tidak logis. Cara melihat ada atau tidaknya problem identifikasi adalah dengan melihat hasil estimasi yang meliputi:

a. Adanya nilai standar eror yang besar untuk satu atau lebih koefisien;

b. Nilai estimasi yang tidak mungkin, misalnya variansi eror yang bernilai negatif; dan

c. Adanya nilai korelasi yang tinggi (>0.90) antar koefisien estimasi.

\section{Menilai Kriteria Goodness-of-Fit}

Sebelum menilai kelayakan dari model, langkah yang harus dilakukan adalah menilai apakah data yang akan diolah memenuhi asumsi persamaan struktural. Ada tiga asumsi dasar yang harus dipenuhi untuk dapat menggunakan SEM yaitu:

a. Observasi data independen;

b. Responden diambil secara random; dan

c. Memiliki hubungan linear.

\section{Interpretasi dan Modifikasi Model}

Ketika model telah dinyatakan diterima, maka peneliti dapat mempertimbangkan dilakukannya modifikasi model untuk memperbaiki penjelasan teoritis atau goodness of fit. Modifikasi dari model awal harus dilakukan setelah dikaji banyak pertimbangan. Jika model dimodifikasi, maka model tersebut harus diestimasi dengan data terpisah sebelum model modifikasi diterima.

\section{HASIL DAN PEMBAHASAN}

Analisis ini digunakan untuk melakukan perhitungan indeks kepemilikan sepeda motor dan karakteristik bepergian menggunakan metode SEM (Structural Equation Modeling). Analisis SEM dilakukan dengan bantuan Software AMOS 22. AMOS dipilih karena penggunaanya yang cukup mudah, dan software AMOS cukup populer digunakan dalam analisis data SEM. Adapun langkah-langkah analisis SEM adalah sebagai berikut: 


\section{Pengembangan Model Teoritis}

Perhitungan indeks kepemilikan sepeda motor terhadap karakteristik bepergian terdiri dari 2 komponen besar sebagai dasar perhitungan. Pertama adalah kepemilikan sepeda motor. Kepemilikan kendaraan dapat dipengaruhi oleh beberapa faktor, salah satunya adalah faktor sosio ekonomi, yaitu yang berhubungan dengan perilaku masyarakat baik selaku pengguna jalan maupun bukan pengguna jalan.

Kedua adalah karakteristik bepergian, yaitu kebutuhan dan aktivitas harian masyarakat MBR yang cukup beragam menyebabkan lokasi dan tujuan bepergian menjadi beragam. Beberapa faktor yang mendasari timbulnya karakteristik bepergian berhubungan dengan tujuan mereka melakukan perjalanan diantaranya kebutuhan akan sarana dan prasaranan publik yang tidak ataupun belum tersedia baik didalam maupun disekitar kawasan mereka bermukim, seperti bekerja, sekolah, berbelanja, rekreasi, olahraga, kesehatan, serta mengunjungi kerabat.

Berdasarkan teori tersebut, maka dapat terbentuk 2 konstruk dan masing - masing konstruk memiliki 7 indikator. Konstruk-konstruk yang dibentuk akan disajikan pada Tabel 1.

Tabel 1. Konstruk kepemilikan sepeda motor dan karakteristik bepergian

\begin{tabular}{cllc}
\hline No. & Konstruk & \multicolumn{1}{c}{ Indikator } & Variabel \\
\hline 1 & Kepemilikan sepeda motor & Jarak & $\mathrm{Y}_{1}$ \\
& & Biaya & $\mathrm{Y}_{2}$ \\
& Waktu & $\mathrm{Y}_{3}$ \\
& Modal kerja & $\mathrm{Y}_{4}$ \\
& Hobi & $\mathrm{Y}_{5}$ \\
& Simbol kesuksesan dan & $\mathrm{Y}_{6}$ \\
& kemapanan & $\mathrm{Y}_{7}$ \\
& Karakteristik bepergian & Simpanan & $\mathrm{X}_{1}$ \\
& & Bekerja & $\mathrm{X}_{2}$ \\
& & Sekolah & $\mathrm{X}_{3}$ \\
& Kesehatan & $\mathrm{X}_{4}$ \\
& & Berbelanja & $\mathrm{X}_{5}$ \\
& & Rekreasi & $\mathrm{X}_{6}$ \\
& & Olahraga & $\mathrm{X}_{7}$ \\
\hline
\end{tabular}

\section{Pengembangan Diagram Alur}

Berdasarkan teori transportasi yang telah disebutkan di atas, selanjutnya akan dibuat diagram alur hubungan kausalitas antar faktor. Input grafik yang dibuat dengan program AMOS adalah sebagai berikut: 


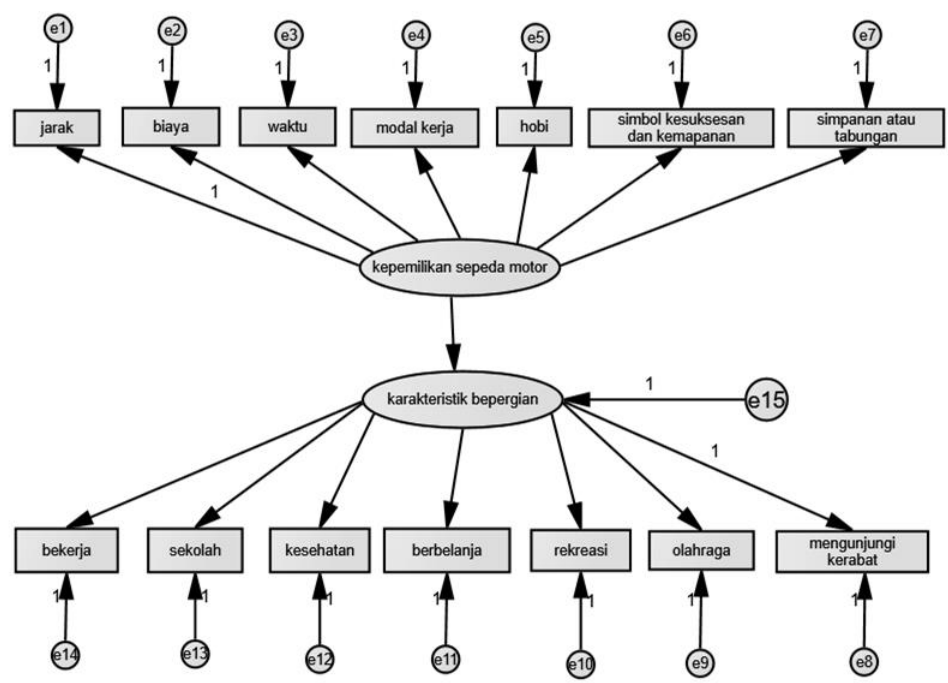

Gambar 1. Grafik input diagram alur kepemilikan sepeda motor dan karakteristik bepergian dengan konstruk kepemilikan sepeda motor dan konstruk karakteristik bepergian

\section{Memilih Matriks Input dan Estimasi yang Diusulkan}

Penelitian ini bertujuan untuk mengeksplorasikan pola saling hubungan, sehingga matriks yang digunakan adalah matriks dalam bentuk korelasi. Program AMOS akan mengkonversikan dari data mentah ke bentuk kovarian atau korelasi lebih dahulu sebagai input analisis. Model estimasi standard AMOS adalah menggunakan estimasi maksimum likelihood (ML). Estimasi ML menghendaki terpenuhinya asumsi:

a. Jumlah sampel besar

Jumlah sampel yang digunakan dalam penelitian ini adalah 371 sampel, jumlah tersebut dapat dikategorikan ke dalam sampel besar.

b. Data berdistribusi normal multivariat

Berdasarkan output software AMOS diperoleh bahwa data telah memenuhi asumsi normal multivariat.

c. Model yang dihipotesiskan valid

Model yang dihipotesiskan telah didasari pada teori transportasi yang ada. Didukung dengan nilai validitas standardized regression weight bahwa tidak ada variabel dengan nilai di bawah 0.5 , sehingga variabel-variabel bentukan yang disajikan pada model tersebut sudah dapat memenuhi asumsi valid.

Setelah model hipotesis dan matriks data diinput, maka diperoleh hasil analisis sebagai berikut: 


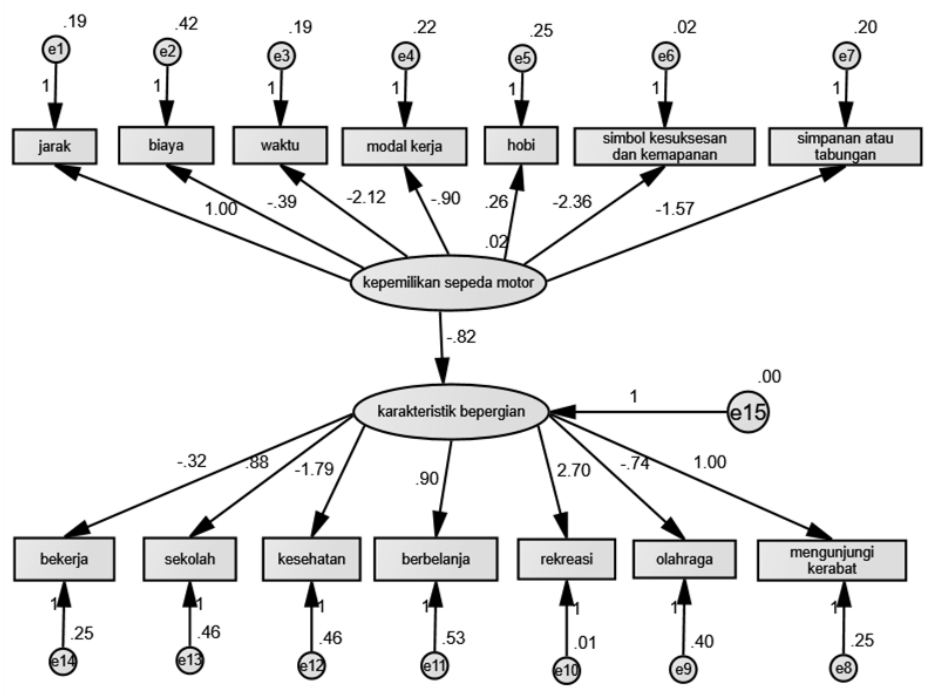

Gambar 2. grafik output diagram alur kepemilikan sepeda motor dan karakteristik bepergian

\section{Konversi Diagram Alur ke dalam Persamaan Struktural dan Model Pengukuran}

a. Model persamaan struktural

$\eta 1=\gamma 11 \xi 1+\beta 11 \xi 1+\zeta 1$

Dengan:

$\eta 1=$ Konstruk karakteristik bepergian

$\xi 1=$ Konstruk kepemilikan sepeda motor

$\zeta 1=$ kesalahan struktural pada konstruk kepemilikan sepeda motor

b. Model pengukuran peubah tak bebas

$$
\begin{aligned}
\mathrm{Y}_{1} & =\lambda_{11} \eta_{1}+\varepsilon_{1} \\
\mathrm{Y}_{2} & =\lambda_{21} \eta_{1}+\varepsilon_{2} \\
\mathrm{Y}_{3} & =\lambda_{31} \eta_{1}+\varepsilon_{3} \\
\mathrm{Y}_{4} & =\lambda_{41} \eta_{1}+\varepsilon_{4} \\
\mathrm{Y}_{5} & =\lambda_{51} \eta_{1}+\varepsilon_{5} \\
\mathrm{Y}_{6} & =\lambda_{61} \eta_{1}+\varepsilon_{6} \\
\mathrm{Y}_{7} & =\lambda_{71} \eta_{1}+\varepsilon_{7}
\end{aligned}
$$

Atau dalam bentuk matriks

$$
\left[\begin{array}{c}
\mathrm{Y}_{1} \\
\mathrm{Y}_{2} \\
\mathrm{Y}_{3} \\
\mathrm{Y}_{4} \\
\mathrm{Y}_{5} \\
\mathrm{Y}_{6} \\
\mathrm{Y}_{7}
\end{array}\right]=\left[\begin{array}{ll}
\lambda_{11} & 0 \\
\lambda_{21} & 0 \\
\lambda_{31} & 0 \\
\lambda_{41} & 0 \\
\lambda_{51} & 0 \\
\lambda_{61} & 0 \\
\lambda_{71} & 0
\end{array}\right]\left[\begin{array}{l}
\eta_{1} \\
0
\end{array}\right]+\left[\begin{array}{c}
\varepsilon_{1} \\
\varepsilon_{2} \\
\varepsilon_{3} \\
\varepsilon_{4} \\
\varepsilon_{5} \\
\varepsilon_{6} \\
\varepsilon_{7}
\end{array}\right]
$$

c. Model pengukuran peubah bebas

$$
\begin{aligned}
& \mathrm{X}_{1}=\lambda_{11} \xi_{1}+\delta_{1} \\
& \mathrm{X}_{2}=\lambda_{21} \xi_{1}+\delta_{2} \\
& \mathrm{X}_{3}=\lambda_{31} \xi_{1}+\delta_{3} \\
& \mathrm{X}_{4}=\lambda_{41} \xi_{1}+\delta_{4} \\
& \mathrm{X}_{5}=\lambda_{51} \xi_{1}+\delta_{5}
\end{aligned}
$$




$$
\begin{aligned}
& \mathrm{X}_{6}=\lambda_{61} \xi_{1}+\delta_{6} \\
& \mathrm{X}_{7}=\lambda_{71} \xi_{1}+\delta_{7}
\end{aligned}
$$

Atau dalam bentuk matriks

$$
\left[\begin{array}{l}
\mathrm{X}_{1} \\
\mathrm{X}_{2} \\
\mathrm{X}_{3} \\
\mathrm{X}_{4} \\
\mathrm{X}_{5} \\
\mathrm{X}_{6} \\
\mathrm{X}_{7}
\end{array}\right]=\left[\begin{array}{ll}
\lambda_{11} & 0 \\
\lambda_{21} & 0 \\
\lambda_{31} & 0 \\
\lambda_{41} & 0 \\
\lambda_{51} & 0 \\
\lambda_{61} & 0 \\
\lambda_{71} & 0
\end{array}\right]\left[\begin{array}{l}
\xi_{1} \\
0
\end{array}\right]+\left[\begin{array}{l}
\delta_{1} \\
\delta_{2} \\
\delta_{3} \\
\delta_{4} \\
\delta_{5} \\
\delta_{6} \\
\delta_{7}
\end{array}\right]
$$

\section{Menilai identifikasi Model Struktural}

Berdasarkan output analisis data pada lampiran 12, diperoleh hasil bahwa model kepemilikan sepeda motor dan karakteristik bepergian adalah overidentified. Dengan jumlah sampel $n=371$, total jumlah data kovarian 119 sedangkan jumlah parameter yang akan diestimasi adalah 43. Dari hasil tersebut, maka degree of freedom yang dihasilkan adalah 119-43 = 76, $76>0$ sehingga model tersebut overidentified, sehingga model tersebut dapat diidentifikasikan estimasinya.

\section{Menilai Kriteria Goodness of Fit}

Menilai goodness of fit merupakan tujuan utama dalam SEM, yaitu ingin mengetahui sampai seberapa jauh model yang dihipotesiskan ' $f i t$ ' atau cocok dengan sampel data. Pertama akan dinilai kriteria goodness of fit berdasarkan nilai Chi Square: $\mathrm{H}_{0}: \Sigma=\Sigma(\theta)$ berarti model tidak cocok dengan data observasi $\mathrm{H}_{1}: \Sigma \neq \Sigma(\theta)$ berarti model cocok dengan data observasi

Kriteria keputusan : $\mathrm{H}_{0}$ ditolak jika nilai $(\mathrm{n}-1) \mathrm{FML}(\mathrm{S}, \Sigma(\theta)) \leq \mathrm{X}_{21-\alpha}(\mathrm{db})$, diharapkan nilai probability adalah $<0,05$ (Hair et al., 2006). Hasil goodness of fit seperti terlihat pada Chi-square 945.824 , dengan $\mathrm{df}=76$ dan nilai probability adalah 0,00 yang menunjukkan bahwa nilai $\mathrm{X}_{21-\alpha}(\mathrm{db})=991,2138$. Hal ini berarti model yang dihipotesiskan telah cocok dengan data observasi. Kecocokan model juga didukung dengan nilai $\mathrm{GFI}=0,964$, nilai TLI $=0,915$, nilai $\mathrm{RMSEA}=0,068$. Nilai GFI dan TLI berada di atas nilai 0,9 dan nilai RMSEA berada antara interval 0,03 sampai 0,08 sehingga model dikatakan cocok terhadap data observasi.

\section{Intepretasi Model dan Modifikasi Model}

Model yang dihipotesiskan telah memenuhi seluruh kriteria yang dibutuhkan, sehingga tidak perlu diadakan modifikasi model. Model yang dihipotesiskan sebelumnya telah cocok digunakan untuk perhitungan indeks kepemilikan sepeda motor dan karakteristik bepergian. Maka selanjutnya yang dilakukan adalah menginterpretasikan model tersebut. Sebelum menginterpretasikan model persamaan struktural yang terbentuk, akan dijelaskan descriptive statistic dari data yang menjadi sampel penelitian.

Terdapat beberapa alasan yang mendasari kepemilikan sepeda motor antara lain, kesenjangan jarak, biaya transportasi yang relatif lebih murah, waktu tempuh relatif lebih cepat, sebagian besar sepeda motor digunakan sebagai alat dan/atau modal bekerja, 
sepeda motor sebagai media penyalur hobi, sebagai simpanan dan tabungan keluarga, serta sebagai simbol kesuksesan dan kemapanan seseorang.

Berdasarkan hasil penelitian diketahui bahwa faktor jarak memiliki persentase tertinggi dengan 16,8\% yang disusul faktor simpanan dan modal kerja dengan persentase masing masing $15,6 \%$ dan $15,5 \%$. Sedangkan faktor yang paling rendah pengaruhnya adalah faktor biaya dengan persentase sebesar $11,7 \%$. Hal ini menunjukkan bahwa biaya bukan merupakan faktor utama yang memperngaruhi kepemilikan sepeda motor di kalangan masyarakat berpedapatan rendah di Kota Makassar, melainkan faktor kesenjangan jarak yang menjadi faktor utama. Nilai ini memperkuat data observasi dan wawancara yang diperoleh dilapangan bahwa hampir keseluruhan masyarakat MBR mengalami kendala kesenjangan jarak dari rumah ke sarana dan prasarana publik disebabkan lokasi hunian yang terletak jauh dari pusat kota serta fasilitas transportasi di kawasan permukiman tersebut yang tidak memadai.

Diketahui bahwa faktor tempat kerja memiliki persentase tertinggi dengan $16,6 \%$ yang disusul faktor mengunjugi kerabat dan rekreasi dengan persentase masing masing $15,1 \%$ dan $14,8 \%$. Sedangkan faktor yang paling rendah pengaruhnya adalah faktor olahraga dengan persentase sebesar $11,8 \%$. Hal ini menunjukkan bahwa faktor tempat kerja menjadi faktor utama lokasi bepergian sebagian besar masyarakat berpendapatan rendah di Kota Makassar. Dari gambaran tersebut diketahui bahwa masyarakat berpendapatan rendah memiliki beragam tujuan bepergian mengingat seluruh kebutuhan sandang, pagan maupun papan masyarakat tidak sepenuhnya tersedia disekitar tempat mereka bermukim, pilihan yang tersedia juga terbatas, ragam fasilitas publik yang minim menjadi sampel penyebab munculnya karakteristik bepergian pada masyarakat berpendapatan rendah, utamanya bagi mereka yang bermukim di area pinggiran kota.

Dalam penelitian ini, data diperoleh dengan survei pengaruh kepemilikan sepeda motor terhadap karakteristik bepergian yang dilakukan terhadap 371 responden masyarakat berpendapatan rendah. Jumlah responden sebanyak $371 \mathrm{KK}$ dipilih karena SEM mengharapkan jumlah sampel yang cukup besar, dan untuk melakukan estimasi dengan metode maximum likelihood dibutuhkan sampel minimal 100 (Hair et al., 2006). Data diperoleh dengan cara membagikan 371 kuesioner kepada responden yang diambil di empat lokasi berbeda yaitu kawasan permukiman di Kelurahan Untia, kawasan permukiman di Kelurahan Buloa, kawasan permukiman di Kelurahan Banta-bantaeng, dan kawasan permukiman di Kelurahan Baraya, dengan dibantu beberapa pihak. Kuesioner tersebut dibagikan di rumah masing masing responden.

Sebagaimana pernyataan sebelumnya telah disebutkan bahwa model yang dihipotesiskan telah valid. Maka langkah selanjutnya adalah uji reabilitas dari masing konstruk bentukan. Reabilitas adalah ukuran konsistensi internal dari indikator-indikator sejauh variabel bentukan yang menunjukkan derajat sampai dimana masing-masing indikator itu mengindikasikan sebuah variabel bentukan yang umum. Nilai dari construct reability adalah minimal 0,70 .

a. Sum standardized loading untuk:

Kepemilikan sepeda motor $=1-0,39-2,12-0,90+0,26-2,36-1,57$

$$
=-6,08
$$


Karakteristik bepergian $\quad=1-0,74+2,70+0,90+0,88-1,79-0,32$

$$
=2,63
$$

b. Sum measurement error untuk:

Kepemilikan sepeda motor $=0,19+0,42+0,19+0,22+0,25+0,02+0,20$

$$
=1,49
$$

Karakteristik bepergian $\quad=0,25+0,46+0,46+0,53+0,01+0,40+0,25$

$$
=2,36
$$

Nilai construct reability untuk masing-masing konstruk adalah:

Kepemilikan sepeda motor $=\frac{(-6,08)^{2}}{(-6,08)^{2}+1,49}=0,96$

Karakteristik bepergian $=\frac{(2,63)^{2}}{(2,63)^{2}+2,36}=0,75$

Dapat dilihat bahwa construct reability dari masing-masing konstruk memiliki nilai diatas 0,70 sehingga dapat disimpulkan masing-masing konstruk telah memenuhi syarat reabilitas. Sedangkan untuk Indeks masing-masing konstruk diperlihatkan dengan jumlah varians yang diekstrasi oleh variabel bentukan yang dikembangkan. Nilai extracted yang tinggi menunjukkan bahwa indikator-indikator itu telah mewakili secara baik variabel bentukan yang dikembangkan. Nilai tersebut dapat diperoleh dengan rumus (Ghozali, 1995):

c. Sum of square standardized loading untuk:

Kepemilikan sepeda motor $=1^{2}+(-0,39)^{2}+(-2,12)^{2}+(-0,90)^{2}+0,26^{2}+(-2,36)^{2}+(-1,57)^{2}$

$$
=14,56
$$

Karakteristik bepergian $=1^{2}+(-0,74)^{2}+2,70^{2}+0,90^{2}+0,88^{2}+(-1,79)^{2}+(-0,32)^{2}$

$$
=13,73
$$

Maka persentase indeks untuk masing-masing konstruk adalah:

Kepemilikan sepeda motor $=\frac{(14,56)^{2}}{(14,56)^{2}+1,49}=0,993$

Karakteristik bepergian $=\frac{(13,73)^{2}}{(13,73)^{2}+2,36}=0,987$

Dari proses perhitungan tersebut diperoleh indeks kepemilikan sepeda motor yaitu sebesar 99,3\%. Nilai tersebut merupakan nilai yang tinggi untuk indeks kepemilikan sepeda motor maupun karakteristik bepergian yang membutuhkan nilai minimal $50 \%$ (Alamsyah, 2008). Angka 99,3\% merupakan hasil yang menggembirakan. Diharapkan angka indeks ini dapat dipertahankan, demikian halnya dengan konstruk karakteristik bepergian yang memiliki angka sebesar $98,7 \%$.

\section{KESIMPULAN}

Berdasarkan hasil analisis SEM diketahui bahwa indeks kepemilikan sepeda motor sebesar 99,3\%. Angka ini menunjukkan nilai yang tinggi, hal ini berarti kepemilikan sepeda motor masyarakat berpendapatan rendah di Kota Makassar cukup tinggi. Di 
samping itu nilai koefisien jalur sebesar pada diagram output hasil analisis SEM sebesar 0,82 atau setara dengan $82 \%$ menunjukkan indeks kepemilikan sepeda motor terhadap karakteristik bepergian yang cukup besar.

\section{DAFTAR PUSTAKA}

De Jong, G., Gunn, H., \& Walker, W. (2004). National and international freight transport models: an overview and ideas for future development. Transport Reviews, 24(1), 103-124.

Ghozali, I., \& Fuad. (2008). Structural equation modeling: Teori, konsep, dan aplikasi dengan program Lisrel 8.80. Semarang: Badan Penerbit Universitas Diponegoro.

Gudono, G. (2006). Analisis Arah Kausalitas (Causal Ordering). Journal of Indonesian Economy and Business, 21(1), 75-82.

Hildayanti, A. (2019). Pola Pergerakan Wisatawan pada Kawasan Pariwisata Pantai Kota Makassar. Jurnal Koridor, 10(1), 27-34.

Miro, F. (2005). Perencanaan transportasi: untuk mahasiswa, perencana, dan praktisi. Jakarta: Penerbit Erlangga.

Pongthanaisawan, J., \& Sorapipatana, C. (2010). Relationship Between Level of Economic Development and Motorcycle and Car Ownerships and Their Impacts on Fuel Consumption and Greenhouse Gas Emission in Thailand. Renewable and Sustainable Energy Reviews, 14(9), 2966-2975.

Sharp, R. S., Evangelou, S., \& Limebeer, D.J. (2004). Advances in the Modelling of Motorcycle Dynamics. Multibody system dynamics, 12(3), 251-283.

Spyropoulou, I., \& Sermpis, D. (2007). Parameters Related to Modeling Motorcycle Movement (No. 072856).

Timm, N. H. (2002). Applied multivariate analysis. New York: Springer.

Wedagama, D. P. W. (2009). The Analysis of Household Car and Motorcycle Ownerships Using Poisson Regression (Case Study: Denpasar-Bali). Jurnal Teknik Sipil ITB, 16(2), 103-112. 